\begin{tabular}{lr}
\hline PRACE NAUKOWE UNIWERSYTETU EKONOMICZNEGO WE WROCEAWIU \\
RESEARCH PAPERS OF WROCLAW UNIVERSITY OF ECONOMICS & nr 475 • 2017 \\
\hline Problemy ekonomii, polityki ekonomicznej i finansów publicznych & ISSN $1899-3192$ \\
& e-ISSN 2392-0041
\end{tabular}

\title{
Urszula Zagóra-Jonszta
}

Uniwersytet Ekonomiczny w Katowicach

e-mail: urszula.zagora-jonszta@ue.katowice.pl

\begin{tabular}{l} 
WLASNOŚĆ PAŃSTWOWA \\
W GOSPODARCE DRUGIEJ RZECZYPOSPOLITEJ \\
STATE OWNERSHIP IN THE ECONOMY \\
OF THE SECOND REPUBLIC OF POLAND \\
\hline
\end{tabular}

DOI: $10.15611 /$ pn.2017.475.34

JEL Classification: N94

\begin{abstract}
Streszczenie: Artykuł dotyczy własności państwowej w Drugiej Rzeczypospolitej oraz stanowiska ekonomistów wobec tej kwestii. Sektor państwowy w okresie międzywojennym się rozrastał. Wynikało to nie tylko z celowej polityki rządu (np. z procesu polonizacji wielkich przedsiębiorstw działających na szkodę państwa polskiego), ale również z sytuacji gospodarczej kraju i ogólnoświatowych tendencji. Jednak zarówno przedstawiciele myśli akademickiej, jak i rzecznicy sfer przemysłowych krytycznie odnosili się do aktywnej działalności państwa w gospodarce.
\end{abstract}

Słowa kluczowe: Druga Rzeczpospolita, własność państwowa, akademicka myśl ekonomiczna.

Summary: This article is about state ownership in the Second Republic of Poland and the position of economists in this matter. State sector developed during the interwar period. This was a result of not only a deliberate government policy (for example the process of large companies polonization which operated to the detriment of the Polish state) but also the economic situation of the state and global trends. The representatives of academic thought as well as industrial class spokesmen criticized active state intervention in the economy.

Keywords: the Second Republic of Poland, state ownership, academic economic thought.

\section{Wstęp}

Dwudziestolecie międzywojenne to okres istnienia państwa polskiego, które po 123 latach niebytu na politycznej mapie Europy odzyskało niepodległość i stało się suwerennym podmiotem, który pozostałe kraje musiały zaakceptować i z którym musiały się liczyć. Wroga propaganda niektórych państw, zwłaszcza Niemiec, że Polska to efemeryda, która szybko zniknie, nie ułatwiała trudnej i tak już sytuacji 
zarówno politycznej, jak i gospodarczej. Warto nadmienić, iż po odzyskaniu niepodległości ani jeden odcinek granicy nie był wyznaczony. Należało o nie dopiero walczyć, i to nie tylko drogą dyplomatyczną, ale często zbrojnie (walki o Wilno, o Lwów, o Górny Śląsk).

Celem artykułu jest analiza własności państwowej w Drugiej Rzeczypospolitej oraz stanowiska ekonomistów wobec tej kwestii. Sektor państwowy nie był stabilny; jego zakres się zmieniał, a zmiany te zależały nie tylko od intencji rządzących, ale przede wszystkim od sytuacji gospodarczej kraju, jak również od kapitału zagranicznego, którego udział w polskiej gospodarce był znaczny.

\section{Własność państwowa po odzyskaniu niepodległości}

W spadku po zaborach państwo otrzymało wiele obiektów, które były własnością mocarstw zaborczych i przeszły automatycznie na własność nowo powstałego kraju. Nie była to więc świadoma działalność sfer rządzących, o co często ich oskarżano. W tego typu insynuacjach przodował zwłaszcza „Lewiatan”. Owa swoista „spuścizna" po zaborach przedstawiała się następująco:

- po zaborze rosyjskim Polska otrzymała Bank Włościański i Szlachecki, przekształcone następnie w Bank Rolny, tereny węglowe z jedną kopalnią w Zagłębiu Dąbrowskim, hutę „Blachownia” oraz warzelnie soli w Ciechocinku. Kontynuowano również politykę wysokich ceł oraz ubezpieczeń przymusowych nieruchomości ziemskich i miejskich;

- Prusy pozostawiły fabrykę nawozów sztucznych w Chorzowie, rurociągi i stacje wodne (późniejsze Zakłady Wodociągowe na Górnym Śląsku), kopalnie węgla, hutę ołowiu i srebra w Strzybnicy, warzelnie soli w Inowrocławiu, udziały w stoczni gdańskiej i porcie drzewnym w Toruniu;

- na obszarach byłego zaboru austriackiego pozostały Państwowe Żupy Solne, udziały w spółkach akcyjnych Eksploatacji Soli Potasowych, kopalnie „Brzeszcze” i „Spytkowice”, wyłączności węglowe w zachodniej Małopolsce, rafinerie naftowe (późniejszy „Polmin”). W sektorze bankowym własnością państwa były: Pocztowa Kasa Oszczędności, Galicyjski Bank Krajowy oraz Wojenny Zakład Kredytowy [Gołębiowski 1985, s. 29-45; Grabowski 1967, s. 157-158].

Poza tym we wszystkich zaborach własnością państwa była kolej, poczta, telegraf, domeny i lasy, które zostały przejęte przez państwo polskie. Również monopole państwowe działające w różnych zaborach rząd polski rozciągnął na obszar całego kraju. I tak od 1920 r. działała w całym kraju, przejęta po Prusach, Loteria państwowa. Od połowy 1922 r. wszędzie obowiązywał monopol tytoniowy (po zaborze au-

\footnotetext{
${ }^{1}$ Centralny Związek Polskiego Przemysłu, Górnictwa, Handlu i Finansów. Po połączeniu z Górnośląskim Związkiem Przemysłowców Górniczo-Hutniczych w 1932 r. zmienił nazwę na Centralny Związek Przemysłu Polskiego (CZPP). Reprezentował interesy wielkiego kapitału. Na jego czele stał Andrzej Wierzbicki.
} 
striackim), a od 1924 r. monopol solny (istniejący wcześniej na Śląsku Cieszyńskim i w Małopolsce) oraz monopol spirytusowy (po zaborze rosyjskim). W późniejszym czasie powstał jeszcze monopol zapałczany.

Tylko pierwszy rząd, na czele którego stał socjalista - Jędrzej Moraczewski, wysunął hasło nacjonalizacji przemysłu, bojąc się zamieszek spowodowanych wysokim bezrobociem. Formalnie jednak miał o tym zadecydować Sejm, który dopiero tworzono. Ponieważ przemysłowcy nie kwapili się do uruchamiania fabryk, ze względu na niepewną sytuację i obawę przed wywłaszczeniem, rząd podjął akcję uruchamiania przedsiębiorstw, co można uznać za przejaw etatyzmu. Nie wynikało to jednak z założeń doktrynalnych, ale z bierności sfer przemysłowych i z obawy przed rosnącym bezrobociem. Kolejny rząd, powołany w połowie stycznia 1919 r., na czele którego stanął Ignacy Jan Paderewski, odciął się od jakichkolwiek prób nacjonalizacji gospodarki. Minister przemysłu i handlu w tym rządzie, Kazimierz Hącia, zaznaczał: „Należy uważać za rzecz przesądzoną, iż odbudowy przemysłu dokona społeczeństwo drogą inicjatywy prywatnej, jedynie do tego powołanej, a nie czynniki rządowe" [Landau, Tomaszewski 1967, s. 73]. Sejm nie podjął więc dyskusji nad upaństwowieniem gospodarki. Aktywizacja przemysłu dokonywała się dzięki zamówieniom rządowym i subwencjonowaniu prywatnego kapitału przez rząd, co wynikało głównie ze strachu przed rewolucją, tym bardziej że wrzenia rewolucyjne mogły się łatwo przenieść przez wschodnią granicę na ziemie polskie. Bezpośrednia pomoc rządu dla prywatnego kapitału wzmogła się w okresie wojny z Rosją (1919-1920). Dotyczyło to zwłaszcza przemysłu zbrojeniowego, taboru kolejowego i górnictwa.

Wartość majątku państwowego $\mathrm{w}$ przemyśle wzrastała $\mathrm{w}$ pierwszych latach po odzyskaniu niepodległości wraz z terytorialnym powiększaniem się państwa. W 1918 r. wynosiła 32,5 mln zł, w 1921 r. - 97,1 mln zł, a w 1923 r. już 275,1 mln zł. Majątek ten tworzyło w głównej mierze 650 przedsiębiorstw (w tym tylko kilkanaście dużych), drobnych warsztatów produkcyjnych, banków i niewielkich udziałów w przedsiębiorstwach prywatnych [Roszkowski 1982, s. 154-156]. Najbardziej wartościowe były obiekty przejęte na Górnym Śląsku. Tylko kopalnie, hutę w Strzybnicy i fabrykę nawozów w Chorzowie wyceniano łącznie na $146 \mathrm{mln}$ zł, co stanowiło w 1922 r. 53\% wartości całego majątku państwowego w przemyśle [Gołębiowski 1985, s. 47].

Wraz z narastaniem inflacji rozwijała się sieć banków, w tym również państwowych. Główną przyczyną była początkowo konieczność kredytowania ogromnych inwestycji związanych z odbudową infrastruktury gospodarczej po wojnie i scalaniem trzech odrębnych dzielnic kraju w jeden organizm państwowy. Wzmogło to zapotrzebowanie na kredyty długoterminowe, których odzyskanie, ze względu na nasilającą się inflację, okazało się w wielu przypadkach niemożliwe. Należy również zaznaczyć, że system bankowy ziem zaborczych był różny. Najbardziej ucierpiały banki w zaborze rosyjskim, ponieważ Rosjanie w czasie wojny wywieźli aktywa banków w głąb Rosji. W dobrej kondycji pozostawały banki zaboru pruskiego i na 
terenie Górnego Śląska, natomiast banki galicyjskie częściowo straciły, częściowo zyskały, w zależności od tego, czy znajdowały się w bezpośrednim zasięgu działań wojennych czy nie. Władze polskie starały się uniezależnić od banków byłych państw zaborczych, pozwalając na zakładanie wielu prywatnych instytucji bankowych, czemu sprzyjała inflacja. Powstawały także banki państwowe: w 1919 r. Państwowy Bank Rolny, Pocztowa Kasa Oszczędności i Zakład Kredytowy Miast Małopolskich, w 1922 r. Polski Bank Krajowy i Państwowy Bank Odbudowy, które wraz z powstałą w 1909 r. Centralną Kasą Spółek Rolniczych utworzyły w 1924 r. Bank Gospodarstwa Krajowego (BGK). Jego zadaniem było finansowanie i kredytowanie przedsiębiorstw państwowych, inwestycji samorządowych, akcji budowlanych i rolnictwa [Borowski 1928, z. 11; Górecki 1928, s. 71-74]. Na Górnym Śląsku powołano do życia w 1923 r. Bank Śląski, który był oparty po połowie na polskim kapitale państwowym i francuskim prywatnym. Miał za zadanie przejąć finansowanie przemysłu śląskiego z rąk banków niemieckich, jednak jego skromne, jak na potrzeby górnośląskiego przemysłu, rozmiary uniemożliwiły to [Landau, Tomaszewski 1967, s. 294-296]. Do banków państwowych należały też instytucje finansujące działalność socjalną i komunalną miast: Komunalny Bank Kredytowy (1912 r.), Polski Bank Komunalny (1919 r.), Bank Budowlany (1920 r.). Nie odegrały jednak większej roli ze względu na szczupłe środki, jakimi dysponowały. W zakres sektora państwowego wchodziły też komunalne i gminne kasy oszczędności, które umożliwiały oszczędzanie biedniejszej części społeczeństwa [Zagóra-Jonszta 1989, nr 4, s. 52]. Od 1922 r. własnością skarbu państwa była także Polska Krajowa Kasa Pożyczkowa, centralny bank biletowy emitujący marki polskie. Prowadziła politykę subwencjonowania prywatnego życia gospodarczego przez państwo za pomocą kredytów.

\section{Rozwój sektora państwowego w dwudziestoleciu międzywojennym}

Etatyzm nie mieścił się w programie sfer rządzących. Dlatego po zakończeniu wojny z Rosją i wraz z przejściem do gospodarki pokojowej, pod wpływem powszechnej opinii o konieczności powrotu do gospodarki liberalnej, podjęto decyzję o sprzedaży części przedsiębiorstw państwowych i udziałów państwa w przedsiębiorstwach prywatnych. Do prywatyzacji przeznaczono kopalnie „Spytkowice” i „Brzeszcze”, hutę „Blachownia”, akcje zakładów amunicyjnych „Pocisk”. Tendencja ta nie utrzymała się jednak długo. Spadek udziału sektora państwowego w majątku Polski w latach 1926-1929 nie tylko został zahamowany w latach wielkiego kryzysu gospodarczego, ale tendencja się odwróciła i do końca okresu międzywojennego wartość udziału państwa rosła, zwłaszcza na skutek przejmowania zadłużonych lub działających na szkodę państwa polskiego dużych obiektów przemysłowych będących własnością kapitałów obcych, głównie niemieckich. Ponadto ze względów strategicznych prawie cały przemysł zbrojeniowy był państwowy. W 1929 r. sektor państwowy zatrud- 
niał 26\% ogółu pracowników najemnych (bez robotników rolnych), a ich dochody stanowiły 35\% ogółu płac, co świadczyło o wyższych zarobkach w tym sektorze [Grabowski 1963, s. 87]. Wielki kryzys wielokrotnie zmuszał państwo do przejmowania akcji i udziałów spółek prywatnych, zadłużonych w bankach państwowych, które rząd postanowił sanować lub odebrać z rąk obcego kapitału. W ten sposób na własność państwa przeszły między innymi pakiety akcji przemysłu chemicznego „Boruta”, Zakłady Chemiczne „Grodzisk” i spółka akcyjna „Azot” w Jaworznie. Spolonizowano również jeden z największych zakładów włókienniczych w Europie - Zjednoczone Zakłady K. Scheiblera i L. Grohmana oraz przejęto większościowy pakiet akcji Towarzystwa Zakładów Żyrardowskich. W 1934 r. państwo za pośrednictwem Banku Gospodarstwa Krajowego przejęło 52\% akcji huty „Pokój”. W latach 1934-1937 realizowano przejmowanie największego kompleksu zakładów górniczo-hutniczych „Wspólnota Interesów” [Gołębiowski 1985, s. 174 i nast.]. W 1934 r., ze względu na ogromne zaległości podatkowe, wzięto pod zarząd przymusowy majątek księcia pszczyńskiego. W czerwcu 1939 r. rząd ustanowił nadzór sądowy nad Towarzystwem Akcyjnym Hohenlohe Werke w Wełnowcu [Zagóra-Jonszta 2014, s. 453-456]. W ten sposób wartość majątku państwowego rosła. Dzięki akcji polonizacyjnej górnośląskiego przemysłu opracowano program inwestycyjny modernizujący polskie hutnictwo i przywracający mu rentowność [Popkiewicz, Ryszka 1959, s. 411-412].

Mimo prowadzonych równolegle działań, mających na celu prywatyzację obiektów państwowych, ich zakres był nieznaczny i nie zahamował rozrostu sektora państwowego. W 1935 r. kapitały zakładowe wszystkich krajowych spółek akcyjnych wynosiły $3253 \mathrm{mln}$ zł, z czego na kapitały państwowe przypadało prawie 654 tys. zł, czyli ok. 20,1\% [Gradowski 1965, s. 24-25]. Prawie połowa kapitałów państwowych była ulokowana w przedsiębiorstwach prywatnych. W $1936 \mathrm{r}$. wartość majątku państwa w monopolach stanowiła zaledwie 2,5\% ogólnej sumy udziałów państwa w przemyśle, transporcie, handlu i budownictwie i 11\% sumy kapitałów zakładowych wszystkich krajowych spółek akcyjnych [Mały rocznik statystyczny 1939, s. 110]. Dochody z monopoli państwowych stanowiły jednak znaczącą pozycję we wpływach z podatków pośrednich i nie zawodziły nawet w kryzysie.

W 1931 r. skarb państwa miał największe udziały w przedsiębiorstwach komunikacyjnych ( $8188 \mathrm{mln}$ zł, w tym PKP - $7640 \mathrm{mln}$ zł), bankach państwowych (460,9 mln zł), monopolach (266,9 mln zł), przedsiębiorstwach (180,9 mln zł), lasach i portach handlowych. Razem stanowiło to ponad 95\% ogólnej sumy kapitałów państwowych [Roszkowski 1972, s. 73]. W sektorze prywatnym najwięcej kapitałów państwowych było w komunikacji $(48,2 \%)$, przemyśle metalowym $(17,3 \%)$, górnictwie $(12,7 \%)$, bankach $(9,2 \%)$ i portach handlowych $(8,5 \%)$ [Gradowski 1965, s. 20-21]. Szacowano, że w 1927 r. wartość majątku państwowego stanowiła $12-15 \%$ całego majątku narodowego, a w 1932 r. już ok. 20\% [Heydel 1932, s. 78; Grabowski 1963, s. 87]. Brak jest dokładnych danych, więc w literaturze pojawiały się różne szacunki. 


\section{Zakres działalności państwa w poglądach ekonomistów - akademików oraz wyrazicieli sfer przemysłowych}

Myśl akademicka w przeważającej większości była liberalna. Polscy profesorowie ekonomii byli bardzo sceptyczni wobec dokonujących się zmian w gospodarce, która wymagała coraz większego udziału państwa. Już poznański zjazd prawników i ekonomistów w 1922 r. starał się określić dozwolone granice działalności państwa w sferze ekonomicznej. Stanisław Głąbiński, profesor Uniwersytetu Lwowskiego, zaznaczał, iż ,[...] państwo, prowadząc własne przedsiębiorstwa tylko w zakresie zakładów użyteczności publicznej, w innych dziedzinach może i winno poprzestawać na czuwaniu nad życiem gospodarczym pod hasłem troski o dobro publiczne i wyrównywanie sprzecznych interesów poszczególnych grup i warstw społecznych" [VII Zjazd... 1922, s. 2-3]. Akceptował etatyzm w obszarach powszechnie przyjętych, takich jak komunikacja, poczta, sprawy socjalne. Rozrost sektora państwowego prowadził do ,zbiurokratyzowania społeczeństwa, osłabienia i znieczulenia samodzielności i sił wytwórczych narodu, zabierał społeczeństwu często najdzielniejsze siły techniczne, oświatowe, handlowe, lekarskie, aby [...] marniały przy biurkach urzędowych". Ciężar utrzymania licznej rzeszy biurokratów i pokrywania strat nieudolnie administrowanych przedsiębiorstw ponosi całe społeczeństwo [Głąbiński 1922, s. 464-465].

Najostrzej wszelkie przejawy aktywności państwa w gospodarce zwalczali przedstawiciele tzw. szkoły krakowskiej z Adamem Krzyżanowskim, Adamem Heydlem i Ferdynandem Zweigiem na czele. Krytykowali zwłaszcza etatyzm, który był jawnym pogwałceniem zasad liberalizmu gospodarczego. Krzyżanowski stawiał znak równości między etatyzmem, socjalizmem i kapitalizmem państwowym [Krzyżanowski 1928, s. 19]. Oskarżał etatyzm o ograniczenie wolności na skutek nadmiernej biurokracji, duże koszty utrzymania sektora państwowego, zbyt wysokie obciążenia podatkowe prowadzące do pauperyzacji społeczeństwa i dekapitalizacji majątku, spadek moralności społeczeństwa, zanik twórczej inicjatywy jednostki, ograniczenie demokracji parlamentarnej.

Zdaniem liberałów, na skutek etatystycznej polityki państwa, gospodarka nie mogła osiągnąć stanu równowagi, mechanizm rynkowy nie działał, zanikał motyw zysku i w konsekwencji następowało zahamowanie wzrostu gospodarczego. Tym samym uznawali, że każda działalność państwa, wykraczająca poza powszechnie przyjęte ramy, polegające głównie na zapewnieniu bezpieczeństwa (wewnętrznego i zewnętrznego), ładu i porządku społecznego oraz skromnej pomocy najuboższym, może być przedmiotem krytyki. Według A. Heydla „Etatyzm to nadmierny rozrost gospodarki publicznej", który stał się faktem w latach powojennych [Heydel 1932, s. 75]. Rozrost sektora państwowego oznaczał niegospodarność i nierentowność jego przedsiębiorstw. Wynikało to z formy własności, która nie pozwalała na bankructwo, przez co straty stanowiły koszt państwa [Zweig 1932, s. 320]. Zarzucano 
również przedsiębiorstwom państwowym, że korzystały z uprzywilejowanej pozycji względem sektora prywatnego w zakresie podatków, kredytów, pierwszeństwa w zamówieniach rządowych.

Jan Stanisław Lewiński, profesor Szkoły Głównej Handlowej, zarzucał etatyzmowi wypaczenie praw ekonomicznych, przez co zanikła zasada gospodarności [Lewiński 1934, s. 16]. Roman Rybarski, profesor Uniwersytetu Warszawskiego, podtrzymywał tezę Krzyżanowskiego o „zesumowaniu etatyzmów trzech zaborów” [Rybarski 1933, s. 99-100] i nierentowności sektora państwowego [Rybarski 1929, s. 6-7; Rybarski 1937, s. 79]. Wprawdzie pod wpływem doświadczeń kryzysowych ocena etatyzmu nieco złagodniała, jednak do końca okresu międzywojennego przeważał w opinii przedstawicieli myśli akademickiej pogląd, że im więcej swobody mają podmioty gospodarcze, tym efektywniej działają. Dopuszczano jednak ostrożną ingerencję państwa, której granicą była „konieczność utrzymania wolnej gry podaży i popytu w takich rozmiarach, by w każdej dziedzinie mogła ona służyć za drogowskaz produkcji" [Taylor 1932, s. 672]. Skuteczność interwencji miała polegać na popieraniu, pobudzaniu i koordynowaniu prywatnej działalności, nie zaś na jej zastępowaniu [Taylor 1834, s. 12].

Dopuszczano działalność państwa w zakresie świadczeń publicznych oraz zaspokajania kolektywnych potrzeb, przy zachowaniu właściwych proporcji, ponieważ uważano, że inwestycje publiczne dokonują się kosztem zaspokajania potrzeb indywidualnych [Heydel 1932, s. 15-16]. Podobnie Tadeusz Brzeski z Uniwersytetu Warszawskiego postulował, aby usunąc przedsiębiorstwa państwowe z produkcji czysto gospodarczej, natomiast zostawić, jeśli służą celom ogólnospołecznym [Brzeski 1928, s. 127].

R. Rybarski, starając się dokładnie wyznaczyć granicę działalności państwa, wymieniał trzy obszary:

- represyjny, przeciwstawiający się nadużyciom wolności gospodarczej, zapobiegający powstawaniu prywatnych monopoli, poprzez system prawny chroniący słabszych producentów, akcjonariuszy i konsumentów,

- uzupełniający, kiedy państwo inwestowało w mniej dochodowe dziedziny, do których kapitał prywatny się nie kwapił (regulacja rzek, budowa portów, produkcja broni),

- kierowniczy, polegający na zakreśleniu wyraźnych ram działalności gospodarczej. Dotyczył prowadzenia odpowiedniej polityki handlowej oraz skierowania prywatnych inwestycji na obszary wymagane przez interes państwa, co można było osiągnąć poprzez odpowiednią informację [Rybarski 1934, s. 43-45]. Były to te sfery gospodarki narodowej, do prowadzenia których państwo jest powołane. Poza tym działalność państwa uzasadniona bywała też względami pozagospodarczymi, narodowymi, jak w przypadku przemysłu zbrojeniowego, robót publicznych (ale w ograniczonym zakresie), leśnictwa [Rybarski 1939, s. 141]. Krytyka własności państwowej przez większość przedstawicieli myśli akademickiej wynikała z wyznawanych założeń ekonomii neoklasycznej, miała więc 
podłoże doktrynalne. Inaczej rzecz wyglądała w przypadku ekonomistów, będących rzecznikami sfer przemysłowych. Ci krytykowali rozrost sektora państwowego z pozycji zagrożonych interesów wielkiego przemysłu. Najczęściej więc przedmiotem ataków były przedsiębiorstwa państwowe konkurujące z prywatnymi. Oskarżano je o nierentowność, chętnie powtarzając tezy akademików. Tadeusz Bernadzikiewicz dowodził, że nie mogą być rentowne, ponieważ nie kierują się motywem zysku. Ponadto, jeśli nawet wykazują niewielką nadwyżkę, to i tak jest ona fikcyjna, bo przedsiębiorstwa te korzystają głównie z kapitałów skarbu państwa, przekazywanych nieodpłatnie za pomocą dotacji budżetowych i nieoprocentowanych pożyczek [Bernadzikiewicz 1932, s. 205]. Ponieważ wykazanie nierentowności było rzeczą trudną ze względu na to, że nie istniał dokładny rejestr przedsiębiorstw państwowych, więc rzecznicy „Lewiatana” domagali się jego sporządzenia, a następnie zbadania ich wyników finansowych. W rezultacie w 1936 r. powołano Komisję do Zbadania Gospodarki Przedsiębiorstw Państwowych. Wśród 36 członków większość stanowili przedstawiciele wielkiego kapitału, co zadecydowało o antyetatystycznym charakterze końcowych rekomendacji [Sprawozdanie Komisji ...]. Nie czekając na komisję, Bernadzikiewicz sporządził wykaz przedsiębiorstw państwowych i na podstawie dostępnych danych obliczył ich średnią rentowność. W latach 1927/1928 1932/1933 wynosiła 2,45\%, natomiast w roku budżetowym 1932/1933 (dno kryzysu) była ujemna - 0,79\% [Bernadzikiewicz 1936, s. 77]. Za rok 1937 wynosiła 0,8\% [Bernadzikiewicz 1937, s. 124]. Zważywszy na sumy dotacji i przywilejów, z jakich korzystały firmy państwowe, było to niewiele. Powszechnie więc uważano, że ciężar utrzymania przedsiębiorstw państwowych spoczywa na sektorze prywatnym. Za szczególnie niesprawiedliwe i nieuzasadnione uważano ich uprzywilejowanie w dostępie do zamówień rządowych, tanich kredytów i ulg podatkowych [Bernadzikiewicz 1936, s. 40-52].

Zdając sobie sprawę ze słabej kondycji kapitału prywatnego, ekonomiści związani z „Lewiatanem” domagali się sprowadzania kapitałów zagranicznych w celu wzmocnienia inwestycji. Istotną przeszkodą był jednak etatyzm, który, ich zdaniem, skutecznie zniechęcał do lokat w Polsce [Gliwic 1930, s. 107; Zagadnienie... 1929, s. 94].

Przedstawiciele i rzecznicy wielkiego kapitału zdawali sobie sprawę, że pomoc państwa dla sektora prywatnego jest konieczna, wręcz się jej domagali i dlatego nie atakowali nadmiernie działalności państwa. Ich krytyka sprowadzała się do postulatów:

- wycofania się państwa z działalności sprawnie prowadzonej przez sektor prywatny,

- zwiększenia rentowności przedsiębiorstw państwowych,

- niekonkurowania w produkcji tych samych wyrobów,

- ograniczenia przywilejów dla sektora państwowego.

Ograniczali więc istnienie własności państwowej do form powszechnie akceptowanych (koleje, poczta, przemysł zbrojeniowy, nieodpłatne zaspokajanie potrzeb kolektywnych itp.) [Sprawozdanie... 1939, s. 267-268]. W interesie wielkiego kapi- 
tału leżały dobre stosunki z rządem, gwarantujące korzystanie z dotacji, kredytów, zamówień rządowych, ulg podatkowych itp.

\section{Zakończenie}

Po odzyskaniu niepodległości rozrost sektora państwowego dokonał się niemal samoistnie, państwo bowiem przejęło w sposób naturalny szereg obiektów, które wcześniej też były własnością państwową, tyle że państw zaborczych. Natomiast słabość, a nieraz i niechęć kapitałów prywatnych do ich odkupienia sprawiły, że chcąc nie chcąc, państwo pozostawało ich właścicielem. Rozrost sektora państwowego nie był intencją rządu. W miarę upływu czasu sektor ten się rozrastał, co czasem wynikało z celowej polityki rządu (polonizacja przemysłu, względy bezpieczeństwa), a czasem z chęci sanowania upadających przedsiębiorstw, które uważano jednak za społecznie pożyteczne. Kapitalizm wkraczał w nową fazę gospodarki państwowo-monopolistycznej, którą cechowała narastająca koncentracja kapitału i produkcji oraz wzrost aktywności gospodarczej państwa. Proces ten miał charakter ogólnoświatowy i Polska nie była wyjątkiem. Natomiast specyfika polskiej sytuacji polegała na znacznym zakresie własności państwowej w praktyce i powszechnej krytyce w teorii. Można więc postawić tezę, że teoria nie nadążała za praktyką.

\section{Literatura}

VII Zjazd Prawników i Ekonomistów Polskich w Poznaniu w dniach 3-5 czerwca 1922, Księgarnia Św. Wojciecha, Poznań.

Bernadzikiewicz T., 1932, Zagadnienie rentowności przedsiębiorstw państwowych, Towarzystwo Wydawnicze Młodych Prawników i Ekonomistów, Warszawa.

Bernadzikiewicz T., 1936, Przerosty etatyzmu, Wydawnictwo Biblioteki Polskiej, Warszawa.

Bernadzikiewicz T., 1937, Mała reforma etatyzmu, Towarzystwo Wydawnicze Młodych Prawników i Ekonomistów, Warszawa.

Borowski W., 1928, Bank Gospodarstwa Krajowego w życiu gospodarczym Polski, Przemysł i Handel, z. 11.

Brzeski T., 1928, Polska jako jednostka gospodarcza (b.d.w.), Lwów.

Gliwic H., 1930, Nieco optymizmu, Wyd. Izby Przemysłowo-Handlowej, Warszawa.

Głąbiński S., 1922, Etatyzm a gospodarstwo narodowe, Ruch Prawniczy i Ekonomiczny, z. 3.

Gołębiowski J., 1985, Sektor państwowy w gospodarce Polski międzywojennej, PWN, Warszawa-Kraków.

Górecki B., 1928, Rola Banku Gospodarstwa Krajowego, Przemysł i Handel 1918-1928, wyd. tygodnika „Przemysł i Handel”, Warszawa.

Grabowski T., 1963, Inwestycje zbrojeniowe w gospodarce Polski międzywojennej, Wydawnictwo Ministerstwa Obrony Narodowej, Warszawa.

Grabowski T., 1967, Rola państwa w gospodarce Polski 1918-1928, PWE, Warszawa.

Gradowski R., 1965, Przyczynek do zagadnienia kapitału państwowo-monopolistycznego $w$ Polsce 1918-1939, Książka i Wiedza, Warszawa. 
Heydel A., 1932, Czy i jak wprowadzać liberalizm ekonomiczny, [w:] A. Heydel, T. Lulek, S. Schmidt, S. Wyrobisz, F. Zweig, Etatyzm w Polsce, Nakładem Towarzystwa Ekonomicznego, Kraków.

Heydel A., 1932, Gospodarcze granice liberalizmu i etatyzmu, [w:] A. Heydel, T. Lulek, S. Schmidt,

S. Wyrobisz, F. Zweig, Etatyzm w Polsce, Nakładem Towarzystwa Ekonomicznego, Kraków.

Krzyżanowski A., 1928, Bierny bilans handlowy, Nakładem Towarzystwa Ekonomicznego, Kraków.

Landau Z., Tomaszewski J., 1967, Gospodarka Polski międzywojennej 1918-1939, t. I - W dobie inflacji 1918-1923, Książka i Wiedza, Warszawa.

Lewiński J.S., 1934, Zasady ekonomii politycznej, t. II, SGH, Warszawa.

Maty rocznik statystyczny, 1939, GUS, Warszawa.

Popkiewicz J., Ryszka F., 1959, Przemyst ciężki Górnego Śląska w gospodarce Polski międzywojennej 11922-1939, Śląski Instytut Naukowy, Opole.

Roszkowski W., 1972, Etatyzm przemysłowy w Polsce w latach kryzysu 1929-1935, Przegląd Historyczny, z. 1.

Roszkowski W., 1982, Kształtowanie się podstaw polskiej gospodarki państwowej w przemyśle i bankowości w latach 1918-1924, PWN, Warszawa.

Rybarski R., 1929, Gospodarka rządów sanacyjnych, Zarząd Główny Stronnictwa Narodowego, Warszawa.

Rybarski R., 1933, Przyszłość gospodarcza Polski, Drukarnia Społeczna, Warszawa.

Rybarski R., 1934, Podstawy narodowego programu gospodarczego, Warszawa.

Rybarski R., 1937, Program gospodarczy, Druk F. Wyszyński i S-ka, Warszawa.

Rybarski R., 1939, Idee przewodnie gospodarstwa Polski, Drukarnia F. Wyszyński i S-ka, Warszawa.

Sprawozdanie Komisji do Zbadania Gospodarki Przedsiębiorstw Państwowych, 1939, Ministerstwo Przemysłu i Handlu, Warszawa.

Taylor E., 1834, Wolność gospodarcza, Uniwersytet Poznański, Poznań.

Taylor E., 1932, O zmierzchu kapitalizmu i nowym ustroju słów kilka, Myśl Narodowa, nr 46.

Zagadnienie etatyzmu w Polsce. Stenogramy przemówień ze Zjazdu u posła Janusza Radziwiłta, 1929, Bank Gospodarstwa Krajowego, Warszawa.

Zagóra-Jonszta U., 1989, To byty banki!, Wektory Gospodarki, nr 4.

Zagóra-Jonszta U., 2014, Proces polonizacji górnośląskiego przemysłu w latach 30. XX wieku, [w:] Polityka ekonomiczna, red. J. Sokołowski, A. Żabiński, Prace Naukowe Uniwersytetu Ekonomicznego we Wrocławiu, nr 348, red. Wydawnictwo Uniwersytetu Ekonomicznego we Wrocławiu, Wrocław.

Zweig F., 1932, Jaki winien być kierunek interwencjonizmu państwowego?, [w:] A. Heydel, T. Lulek, S. Schmidt, S. Wyrobisz. F. Zweig, Etatyzm w Polsce, Nakładem Towarzystwa Ekonomicznego, Kraków. 